TOMА М. Г., кандидат юридичних наук, асистент кафедри кримінального права (Чернівеиький національний університет імені Юрія Федьковича)

УДК 343.2

DOI https://doi.org/10.32842/2078-3736-2019-6-2-23

\title{
СТАНОВЛЕННЯ ІНСТИТУТУ СПЕЦІАЛЬНОЇ КОНФІСКАЦІЇ: СОЦІАЛЬНО-ПРАВОВА ОБУМОВЛЕНІСТЬ
}

У статі проаналізовано еволюцію інституту спеціальної конфіскації, як іншого заходу кримінально-правового характеру. Висвітлено питання актуальності інституту спеціальної конфіскації, його відмінність від конфіскації майна як виду покарання. Описані соціальні та правові обумовленості виникнення інституту спеціальної конфіскації в Україні. Розписана система чинників, які зазвичай використовуються вченими для визначення соціально-правової обумовленості кримінального законодавства, зокрема такі: кримінологічні, нормативні, соціально-економічні, міжнародні й історичні; соціально-економічні, медичні, нормативні та кримінологічні; історичні, нормативно-правові, міжнародно-правові та кримінологічні; соціальні, соціально-економічні, системно-правові; кримінологічні, міжнародні, історичні, нормативно-правові; історичні, кримінологічні, нормативно-правові, міжнародні, соціально-психологічні; кримінологічні, історичні, нормативні, соціально-психологічні, міжнародні й ін.

«Спеціальна конфіскація» як термін на законодавчому рівні регламентована в Законі України «Про внесення змін до Кримінального та Кримінально-процесуального кодексів України стосовно виконання Плану дій щодо лібералізації Європейським Союзом візового режиму для України» № 222-VII від 18 квітня 2013 року, яким доповнено Кримінальний кодекс України статтями 96-1 «Спеціальна конфіскація» та 96-2 «Випадки застосування спеціальної конфіскації», диспозиція яких дала можливість зрозуміти позицію законодавця щодо правової характеристики такого заходу кримінально правового характеру. Спеціальна конфіскація фактично визнається заходом кримінально-правового впливу, що виходить за межі кримінальної відповідальності.

Суттєвим чинником до внесення змін у Кримінальний кодекс України, а саме статті 96-1 та 96-2, є міжнародно-правовий, з огляду на прагнення нашої держави до повномасштабної участі в політичному й економічному житті Європи. Велике значення для вдосконалення вітчизняного законодавства має закордонний досвід, з огляду на відповіді на питання щодо необхідності та доцільності внесення змін у національне законодавство.

Ключові слова: еволюиія, спеціальна конфіскачія, конфіскачія майна соиіальна обумовленість, правова обумовленість, заходи кримінальноправового характеру.

The evolution of the institution of special confiscation as another measure of criminal law is analyzed in the article. The question of the relevance of the institute of special confiscation, its difference from confiscation of property as a type of punishment is covered. The social and legal conditionality of the institution of special confiscation in Ukraine is described. The system of factors commonly

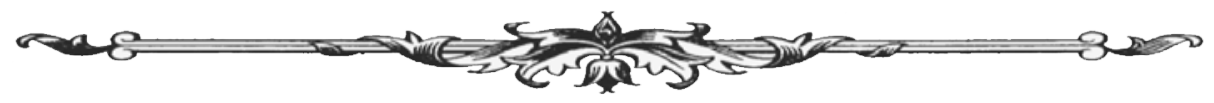


used by scientists to determine the social and legal conditionality of criminal law, including the following: criminological, regulatory, socio-economic, international and historical; socio-economic, medical, regulatory and criminological; historical, regulatory, international and criminological; social, socio-economic, system-legal; criminological, international, historical, regulatory; historical, criminological, regulatory, international, social and psychological; criminological, historical, regulatory, socio-psychological, international, etc.

Special confiscation as a term at the legislative level was regulated in the Law of Ukraine "OnAmendments to the Criminal and Criminal Procedure Codes of Ukraine regarding the Implementation of the European Union Visa Regime Liberalization Action Plan for Ukraine” № 222-VII of April 18, 2013. Supplementing the Criminal Code Ukraine Articles 96-1 "Special confiscation" and 96-2 "Special confiscation cases", the disposition of which made it possible to understand the position of the legislator on the legal characterization of such a measure of criminal nature, which is actually recognized as a measure of criminal influence that goes beyond criminal liability.

A significant factor in the amendment of the Criminal Code of Ukraine, namely Articles 96-1 and 96-2 are international law, in view of our country's desire to participate fully in the political and economic life of Europe. Foreign experience in answering the necessity and expediency of introducing amendments to national legislation is essential for the improvement of national legislation.

Key words: evolution, special confiscation, confiscation of property social conditionality, legal conditionality, measures of criminal nature.

Вступ. Сьогодні в науці кримінального права прийнято вважати одним із головних чинників, що впливають на доцільність реалізації та можливість подальшого ефективного застосування будь-якої кримінально-правової норми, вирішення питання про те, чи виправдані її положення та чи відповідають вони реальним потребам суспільства, тобто з'ясування їхньої соціальної та правової обумовленості. Визначення та розкриття змісту чинників, які доводять соціальну обумовленість кримінального закону, є основним аргументом, який вказує на необхідність кримінального законодавства, яке стоїть на захисті суспільних відносин, дає можливість передбачити розвиток норм чинного кримінального законодавства, а також підвищити рівень наукової обгрунтованості змісту закону [10, с. 123].

Постановка проблеми. Метою дослідження стало питання актуальності інституту спеціальної конфіскації, його становлення в Україні, соціально-правові чинники та доцільність застосування спеціальної конфіскації як іншого заходу кримінально-правового характеру.

Результати дослідження. Проблема соціальної та правової обумовленості кримінального права - широка, багатогранна і давно відома науці кримінального права. Однак головним і1ї аспектом є виявлення та розкриття тих чинників (обставин, умов), які впливають на процес створення кримінального права, та їхньої ефективності.

На шляху до вирішення проблеми соціально-правової обумовленості закону про кримінальну відповідальність загалом і кримінально-правової норми зокрема в теорії кримінального права позиції науковців розділились: одні автори пишуть про соціальні чинники в теорії кримінального права, що обумовлюють криміналізацію та декриміналізацію діяння, інші - власне про соціальну обумовленість норм кримінального законодавства [14, с. 128].

Не деталізуючи погляди вчених, як-от Н.О. Гуторова, М.М. Панов, К.П. Задоя, B.I. Тютюгін, К.А. Новікова, В.С. Батиргареєва й ін., на нашу думку, науковцям варто погодитися $з$ позицією О.А. Пащенко [15, с. 211], що для належного правового аналізу соціально-правової обумовленості слід відокремити умовність кримінально-правової норми соціальної обумовленості криміналізації (декриміналізації) дій від концепції соціальної

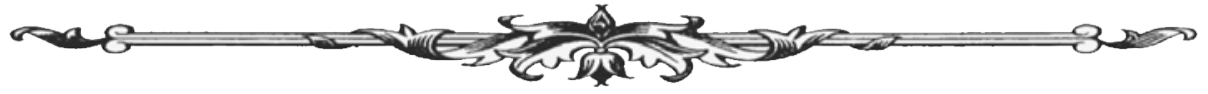


обумовленості права як закону. Переваги обраного підходу можна пояснити тим, що криміналізація є суміжним процесом зі зміною чинного законодавства і $є$ лише одним із можливих наслідків законотворчості (не завжди соціально обумовлена норма знайде свою об'єктивацію в нормах кримінального права), натомість варто визначити питання про соціальну обумовленість правової норми до моменту ухвалення законотворчого рішення про іiі криміналізацію.

Дослідження системи обставин, у результаті яких з’являються ті чи інші кримінально-правові норми, неможливе без уточнення питання, що саме слід розуміти під соціально-правовою обумовленістю кримінально-правові норми. На думку В.І. Борисова, соціально-правова обумовленість кримінального законодавства формується різними соціально-економічними, політичними, психологічними та іншими чинниками, визначення й уточнення яких дає можливість обгрунтувати необхідність кримінально-правового захисту певних суспільних відносин і можливість прогнозування розвитку певних інститутів кримінального права, а також підвищення чинності змісту кримінального законодавства [4, с. 28]. Однак цілком погодитися з думкою В.І. Борисова неможливо, оскільки дещо зменшується важливість правового аспекту соціальної та правової обумовленості норми кримінального законодавство (автор згадує лише соціальні чинники, які вказують на соціальну обумовленість, без правового розмежування чинників, що вказують на юридичну обумовленість норми кримінального права). Натомість доцільно виконувати законодавчу волю у змісті та структурі кримінального права, не обмежуючи соціальні, політичні чи економічні передумови, але які повинні на основі принципів кримінального права, догм та постулатів мати системний характер, відповідати вимогам правозастосовної практики. Інакше правовий аспект якості кримінального закону, пов'язаний із його формою, може негативно впливати на здатність закону ефективно регулювати суспільні відносини, що перебувають під правовим захистом, а також створювати конфлікти та проблеми під час правозастосування на практиці.

Водночас, незважаючи на самостійне значення та важливість і соціально-правові аспекти обумовленості будь-якої норми кримінального права, ми вважаємо, що вони взаємопов'язані і можуть вказувати на доцільність та необхідність взяття певних суспільних відносин під правовий захист лише в єдності. Тому, щоб уникнути термінологічних помилок, повторення та заміни понять, соціальну обумовленість і юридичну обумовленість кримінально-правової норми доцільно розглядати в єдності - термін «соціальна та правова обумовленість».

У науковій літературі можна знайти різні підходи авторів до найменування обставин, що визначають соціальну та правову обумовленість норми кримінального права, а також різні класифікації систем таких обставин. Найчастіше для визначення обставин, що визначають соціальну та правову обумовленість кримінальних норм, використовуються такі терміни, як «фактори», «підстави», «принципи», «чинники», «умови», «критерії», «засоби» [13] тощо. Однак, щоби встановити соціально-правову обумовленість нормою про спеціальну конфіскацію як інший захід кримінально-правового впливу, видається доцільним уживати термін «чинники». Що ж стосується системи чинників, за допомогою яких вона зазвичай учені визначають соціальну та правову обумовленість кримінального закону, варто сказати, що така єдина узагальнена система чинників у науці про кримінальне право також відсутня. Найчастіше використовують: 1) кримінологічні, нормативні, соціально-економічні, міжнародні й історичні; 2) соціально-економічні, медичні, нормативні та кримінологічні; 3) історичні, нормативно-правові, міжнародно-правові та кримінологічні [2]; 4) соціальні, соціально-економічні, системно-правові; 5) кримінологічні, міжнародні, історичні, нормативно-правові; 6) історичні, кримінологічні, нормативно-правові, міжнародні, соціально-психологічні; 7) кримінологічні, історичні, нормативні, соціально-психологічні, міжнародні [3] та ін.

Як ми бачимо, запропоновані чинники системи дещо схожі та певною мірою дублюють один одного. Тому для визначення чинників соціально-правової обумовленості спеціальної конфіскації як іншого заходу кримінально-правового характеру ми вважаємо за необхідне

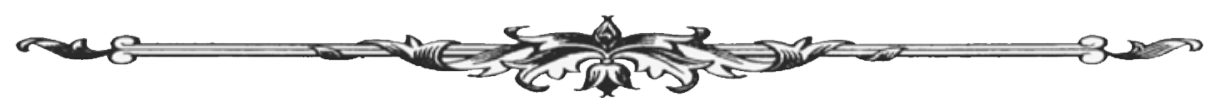


зупинитися на характеристиках тих чинників, з'ясування яких буде достатньою підставою для встановлення того факту, що доцільно ввести розглянуту норму в чинне кримінальне законодавство. Такими чинниками є: історичний; міжнародно-правовий; загально-соціальний (політичний, власне соціальний) та нормативний.

Історичний чинник. Перші правила, пов'язані з конфіскацією майна, містилися у кримінальному праві Київської Русі та земель, утворених після феодальної роздробленості (у IX - на початку XIII ст.). Зокрема, однією з перших збірок архаїчного права була «Руська правда». На іiі основі формувалися інші письмові джерела права, як-от Договори з Візантією 907, 911, 944 та 971 рр., які передбачали таке покарання, як конфіскація. Як найсуворіше покарання, застосоване за тяжкі злочини того часу (вбивства, пограбування, крадіжки, підпал суду), конфіскація майна також була закріплена в розширеному виданні «Руської правди» [16], у кримінальному законодавстві Галицько-Волинського князівства та Литовсько-Російської держави, а також у чинному законодавстві на території української землі в часи перебування України під владою Речі Посполитої (перша половина ХІІІ - перша половина XVII ст.) [8].

Зазвичай у перших нормативних актах, які містили положення щодо конфіскації майна, поняття «спеціальна конфіскація» не вживалося, і всі випадки конфіскації майна називали одним терміном - «конфіскація». Окрім того, більшість нормативно-правових документи, що містять кримінальні та кримінально-процесуальні норми і діяли на території українських земель, фіксували конфіскацію майна як вид покарання (основного чи додаткового).

Перша згадка про спеціальну конфіскацію містилася в Артикулі 33 гл. XIV Литовських статутів 1588 р. ішлося про вилучення підроблених товарів і обладнання (якщо їх виявлено), таку незаконну та заборонену діяльність, як виробництво та продаж у таємних пабах пива, горілки та меду [8, с. 47]. Наступний етап розвитку кримінального законодавства України щодо використання спеціальної конфіскації відображений в «Уложенні про покарання кримінальні та виправні» 1845 р., які, крім загальної конфіскації, що застосовується у випадку засудження винних на каторгу або висилку, також містили норму про спеціальну конфіскацію [12].

Період становлення Української незалежної держави (1917-1921 рр.) характеризується розвитком української правової системи в напрямі лібералізації каральної політики, тому Статутом про державний устрій, права та свободи Української Народної Республіки (далі - УНР), також названим Конституцією УНР, від 29 квітня 1918 р. такий вид покарання, як конфіскація майна, скасовано. Але під час встановлення та панування на українських територіях радянської влади законодавці підходять до конфіскації майна знову, зводячи їі визначення до виду покарання, основного або додаткового [6, с. 159].

У низці статей Особливої частини Кримінального кодексу Української Радянської Соціалістичної Республіки (далі - УРСР) 1960 р. передбачено положення про конфіскацію предметів - так звана спеціальна конфіскація (наприклад, ст. 211 Кримінального кодексу УРСР, за ввезення, збут, продаж і розповсюдження порнографічних предметів). Хоча до цього виду конфіскації термін «спеціальне конфіскація» не застосовувався на законодавчому рівні, саме наявність у кримінальному праві аналогічних норм стала потужним поштовхом до вивчення правової природи таких засобів кримінально-правового регулювання, як спеціальна конфіскація.

У сучасному українському кримінальному праві до недавнього часу (до 2013 р.) під спеціальною конфіскацією майна розуміли спеціальний примусовий захід, застосований на підставі положень ч. 9 ст. 100 Кримінального процесуального кодексу (далі - КПК) України, яким охоплені предмети, визнані речовими доказами у справі (ст. 98 КПК). По суті спеціальна конфіскація не була видом покарання, полягала у примусовому вилученню в дохід держави знарядь злочину, що належали обвинуваченому, а також грошей, цінностей та інших речей, отриманих злочинним шляхом, тобто це були «інструменти утилізації (розпорядження) речових доказів» [7, с. 192].

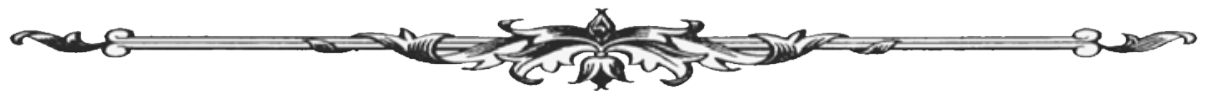


Спеціальну конфіскацію називали конфіскацією майна, що застосовується на підставі приписів окремих статей Особливої частини Кримінального кодексу України (ст. ст. $159^{1}$, 176, 177, 203-1, 203-2, 204, 216, 229, 240, 244, 246, 248, 249, 300, 321 1' 332, 332 ${ }^{1}, 334,369^{3}$ КК України), санкції яких передбачали конфіскацію тих предметів, які чітко визначені статтями (предмети, знаряддя, засоби вчинення злочину, визначені в цих статтях).

На законодавчому рівні термін «спеціальна конфіскація» запроваджений Законом України «Про внесення змін до Кримінального та Кримінального процесуального кодексів України стосовно виконання Плану дій щодо лібералізації Європейським Союзом візового режиму для України» № 222-VII від 18 квітня 2013 р. [3]. Внесення до КК України ст. ст. 96-1 та 96-2, у яких ідеться про спеціальну конфіскацію, дало можливість зрозуміти позицію законодавця щодо правової характеристики спеціальної конфіскації, яка фактично визнається заходом кримінально-правового впливу, що виходить за межі кримінальної відповідальність.

Суттєві зміни та перетворення в підході до законодавчого визначення поняття спеціальної конфіскації, а також до сфери та порядку іiї застосування інститут конфіскації майна зазнав останніми роками, сьогодні він перебуває у стані трансформації. Незважаючи на те, що у введенні спеціальної конфіскації як іншого заходу кримінально-правового характеру в чинному законодавстві України історичний чинник вирішального значення не має, проте такий чинник варто враховувати хоча б тому, що ставлення законодавця до конфіскації майна в різні часи відрізнялося.

Наступним чинником $€$ міжнародно-правовий. 3 огляду на прагнення України до повномасштабної участі в політичному й економічному житті Європи, вагоме значення для вдосконалення національного законодавства та відповіді на питання про необхідність і доцільність внесення законодавчих змін щодо спеціальної конфіскації майна має вивчення закордонного досвіду регулювання та застосування інституту конфіскації майна загалом і спеціальної конфіскації зокрема. Внесення до законодавства України такого виду іншого заходу кримінально-правового впливу, як спеціальна конфіскація, насамперед зумовлено низкою міжнародно-правових актів, що містять рекомендації та зобов'язання щодо впровадження спеціальної конфіскації в нормах національного законодавства України. Серед них такі, як: Угода про асоціацію між Україною, з одного боку, та Європейським Союзом, Свропейським співтовариством з атомної енергії і їхніми державами-членами, з іншого, яка була остаточно підписана 27 червня 2014 р., Кримінальна конвенція про боротьбу з корупцією (ETS 173) від 27 січня 1999 р., Конвенція Організації Об'єднаних Націй проти транснаціональної організованої злочинності від 15 листопада 2000 р. Крім того, Україна є стороною Конвенції Ради Свропи про відмивання, пошук, арешт і конфіскацію доходів, одержаних злочинним шляхом, та про фінансування тероризму від 16 травня 2005 р., взяла на себе зобов'язання щодо встановлення обов'язкових арешту та конфіскації знарядь і засобів злочину, доходів або майна, вартість якого відповідає таким доходам, та відмитого майна за всіма предикатними злочинами, тобто злочинами, за які передбачено покарання у виді позбавлення волі або штрафу понад три тисячі неоподатковуваних мінімумів доходів громадян [1].

Удосконалення кримінального права щодо норми спеціальної конфіскації також відіграє важливу роль у забезпеченні дотримання вимог Європейського Союзу (далі - ЄС) щодо виконання Плану дій Лібералізації візового режиму ЄС для України [2], невід’ємною частиною якої є необхідність імплементації Директиви ЄС від 3 квітня 2014 р. 2014/42/ЄС про арешт та вилучення злочинних предметів діяльність та доходів від неї [17].

Отже, запровадження спеціальної конфіскації майна у статусі іншого заходу кримінально-правового характеру обумовлюється не лише міжнародним досвідом регулювання таких суспільних відносин, а й необхідністю виконання Україною низки міжнародно-правових документів, які містять рекомендації та зобов'язання щодо реалізації спеціальної конфіскації майна в нормах вітчизняного законодавства.

Наступний чинник загально-соціальний. Досліджуючи ролі та значення даного чинника у процесі запровадження спеціальної конфіскації як іншого заходу кримінально-

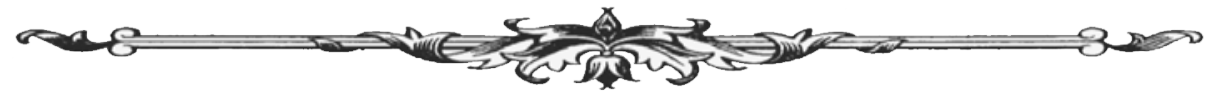


правового характеру в чинному законодавстві України, варто сказати, що поява цього нового інституту кримінального права спричинена суспільною необхідністю та політичною доцільністю. Передусім це виявляється в гостро негативному ставленні суспільства до поширеності такого негативного явища, як корупція, у більшості сфер нашого суспільного життя, усвідомленні нагальної потреби боротьби з негативними явищами, що заважають демократичному шляху розвитку держави. Соціальні зміни, що відбулися в Україні за минулі роки, дають підстави вважати, що законодавчі нововведення щодо регулювання спеціальної конфіскації суперечать усталеній громадській думці. Сьогодні спеціальна конфіскація майна помилково сприймається населенням як засіб, спрямований на ситуативне вирішення проблеми повернення активів представників колишньої влади та наповнення державного бюджету.

Останній чинник, який ми розкриваємо, - нормативно-правовий. Соціально-правові передумови засвідчують, що введення інституту спеціальної конфіскації майна як ще одного чинного кримінально-правового заходу неможливе без правової бази, яка закріплює його законність і дозволяє узгодити його із правовими принципи.

Загальноправовий аналіз міжнародно-правових актів, Конституції України, Кримінального кодексу України, Кримінально-процесуального кодексу України та інших законодавчих актів дає можливість зробити висновок, що імплементація у Кримінальний кодекс України спеціальної конфіскації з подальшими законодавчими змінами свідчить про часткову узгодженість системи кримінального права та кримінально-процесуальних норм, що існували дотепер. Зокрема, вилучення з норм Особливої частини положень про конфіскацію $\epsilon$ порушенням принципу систематичності та правил побудови санкції статей кримінального закону.

Нормативно-правова обумовленість упровадження положень про спеціальну конфіскацію як ефективний засіб боротьби із проявами злочинності розкривається також через наявність у теорії кримінального права критичних позицій окремих авторів, які пропонують вилучити конфіскацію майна із системи покарань України як таку, що: 1) необгрунтовано обмежує приватну власність та права власності членів родини засуджених, які змушені страждати невинно [1, с. 89]; 2) не відповідає принципу конституційно-правової адекватності, яка певною мірою суперечить вимогам ст. ст. 24, 62 та 13 Конституції України [5, с. 61]; 3) несумісний з існуванням демократичної ринково орієнтованої держави [11, с. 47].

Висновки. Проаналізувавши вищезазначені чинники, ми бачимо, що не всі вони однаково безапеляційно вказують на доцільність імплементації спеціальної конфіскації майна як іншого заходу кримінально-правового характеру в чинному кримінальному законодавстві України. Потреба пошуку альтернативи загальній конфіскації майна як інструменту протидії злочинності та подальшого законодавчого врегулювання цього питання продиктована не історичними передумовами, а вимогами сучасної реальності.

\section{Список використаних джерел:}

1. Бажанов М.I., Тацій В.Я. Кримінальне право України. Загальна частина : підручник для студентів юридичних спеціальностей вищих закладів освіти. Київ : Юрінком-Інтер ; Право, 2003. 416 с.

2. Баулін Ю.В. Вибрані праці. Харків : Право, 2013. 928 с.

3. Бєлова О.І. Кримінально-правова характеристика системи злочинів проти сім’ї та неповнолітніх : автореф. дис. ... канд. юрид. наук: 12.00.08. Киъв, 2007. 19 с. ; Гринчак С.В. Порушення встановленого законом порядку трансплантації органів або тканин людини: підстави кримінальної відповідальності : автореф. дис. ... канд. юрид. наук: 12.00.08. Харків, 2007. 20 с. ; Копотун I.M. Громадський порядок як об'єкт кримінально-правової охорони : автореф. дис. ... канд. юрид. наук: 12.00.08. Київ, 2008. 20 с.

4. Борисов В.И. Основные проблемы охраны безопасности производства в уголовном законодательстве Украины : автореф. дис. ... докт. юрид. наук: 12.00.08. Харьков, 1993. $34 \mathrm{c}$.

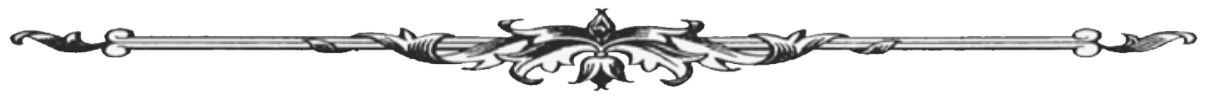


5. Гуторова Н.О. Шаповалова О.А. Конфіскація майна за кримінальним правом України: проблеми та перспективи. Право Украӥни. 2010. № 9. С. 56-65.

6. Єрмак О.В. Конфіскація в кримінальному праві України в періоди радянської державності й у сучасних умовах. Право і суспільство. 2015. № 3 (2). С. 156-162.

7. Карпов К.Н. Иные меры уголовно-правового характера как средство противодействия совершению преступлений : дис. ... канд. юрид. наук: 12.00.08. Омск, 2010. С. 192-193.

8. Ковальов С.Г. Судебник Великого Князя Казимира Ягайловича : монографія. Миколаїв : Вид-во ЧДУ ім. Петра Могили, 2009. 112 с.

9. Кригер Г.А., Кузнецова Н.Ф. Проблемы социальной обусловленности закона. XXV съезд и дальнейшее укрепление сощиалистической законности. Москва, 1977.

C. $113-123$.

10. Мельникова-Крикун В.М. Спеціальна конфіскація. Право та безпека. 2005. Вип. 44. 89 с.

11. Музиченко П.П. Історія держави і права України : навчальний посібник. 6-те вид., перероб. і доповн. Київ : Знання, 2007. 471 с.

12. Осадчий В.І. Проблеми кримінально-правового захисту правоохоронної діяльності : автореф. дис. ... докт. юрид. наук: 12.00.08. Київ, 2004. 36 с. ; Харченко В.Б. Кримінально-правова охорона прав на об'єкти інтелектуальної власності в Україні: перспективи розвитку та гармонізації з європейським законодавством : автореф. дис. ... докт. юрид. наук: 12.00.08. Харків, 2011. 37 с.

13. Пащенко О.О. Дослідження соціальної обумовленості закону України про кримінальну відповідальність (перша половина 90-х рр. ХХ ст.). Питання боротьби зі злочинністю : збірник наукових праць ; редкол. : В.І. Борисов та ін. Харків : Право, 2012. Вип. 24. C. $117-132$.

14. Пащенко О.О. Обставини, що визначають соціальну обумовленість охоронних кримінально-правових норм (законів про кримінальну відповідальність). Актуальні проблеми кримінальної відповідальності : матеріали Міжнародної науково-практичної конференції, 10-11 жовтня 2013 р. ; редкол. : В.Я. Тацій (гол. ред.) та ін. Харків : Право, 2013. С. 210-213.

15. Федорова А.Н. Правонарушение и юридическая ответственность по «Русской правде» : автореф. дис. ... канд. юрид. наук. Тольятти, 2005. 21 с.

16. Directive 2014/42/EU of the European Parliament and of the Council of 3 April 2014 on the freezing and confiscation of instrumentalities and proceeds of crime in the European Union. URL: http://eur-lex.europa.eu/legal-content/EN/TXT/?uri=CELEX\%3A32014L0042.

17. Конвенція Ради Європи про відмивання, пошук, арешт та конфіскацію доходів, одержаних злочинним шляхом, та про фінансування тероризму від 16 травня 2005 р. URL: http://zakon2.rada.gov.ua/laws/show/994_948.

18. План дій для України на 2015-2017 pp. GR-DEM (2015)2 від 13 січня 2015 p. URL: http://www.slg-coe.org.ua/wp-content/uploads/2016/01/Action_Plan_2015_2017_uk.pdf.

19. Про внесення змін до Кримінального та Кримінального процесуального кодексів України (стосовно виконання Плану дій щодо лібералізації Свропейським Союзом візового режиму для України) : Закон України від 18 квітня 2013 р. № 222-VII. Офіиійний вісник України. 2013. № 46. Ст. 1629.

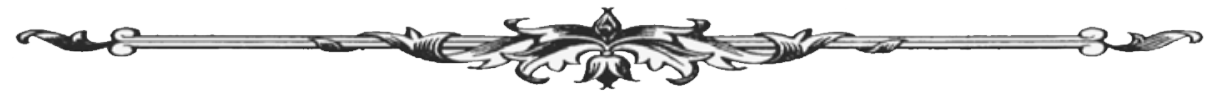

